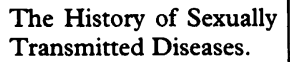
Transmitted Diseases. No. 10 in a series edited by Milton Lewis and Michael Waugh.

\title{
Sexually Transmitted Diseases between Imperial and Nazi Germany
}

\author{
Paul Weindling
}

Adolf Hitler in Mein Kampf feared that the spread of syphilis in Germany before 1914 was poisoning the health of the national body. His phobia might be seen as a response to a widespread public debate on the prevalence of such diseases that had been raging since the 1890s: the arguments between moral purity crusaders and the abolitionists over their attack on police controls on prostitution triggered off three decades of intense public debate conducted in often highly emotive and lurid terms. STDs were perceived as symptomatic of moral, social and physical degeneration, while diagnoses of the causes and the cures of the underlying social ills ranged from feminist attacks on double standards of morality to ultra-conservative insistence on patriarchy, discipline and sexual abstinence. The arguments must have captured the imagination of wide sections of the population.

The launching of these debates was in no small way due to the dermatologist and social reformer Alfred Blaschko (1858-1922) who took a key role in the foundation of the Deutsche Gesellschaft für die Bekämpfung der Geschlechtskrankheiten, or DGBG (the German Society for the Prevention of Sexually Transmitted Diseases), in $1902 .^{1}$ From 1902 until 1916 he was the energetic Secretary of the DGBG, and from 1916 until 1922 he was its chairman. The DGBG was pioneering both nationally and internationally in educating the public about the risks of STDs. Blaschko endeavoured to enlighten both the medical profession and general public. He was editor of the DGBG's publications, notably of its widely disseminated Mitteilungen. $^{2}$ Personal acquaintance with leading medical researchers like Paul Ehrlich (1854-1915) and August von Wassermann (1866-1925) in Berlin meant that Blaschko was well placed to evaluate innovations in therapy and diagnosis, and he could draw on his extensive experience of clinical medicine and social conditions in the expanding metropolis. ${ }^{3}$

From 1888 Blaschko specialised as a dermatologist, and built up a thriving practice. He had a private surgery and a large and well equipped Policlinic für Haut- und Geschlechtskrankheiten where medically insured patients were seen. The practice provided a stable basis for independent research, as well as becoming a centre for specialist training. ${ }^{4}$ Blaschko saw patients between 9 am and $2 \mathrm{pm}$. Thereafter he devoted himself to scientific and public activities in numerous societies and associations. ${ }^{5}$ This combination of clinical experience and broad scientific interests led to the discovery of the "lines of Blaschko" in 1901.6 His scientific reputation was established by a textbook, published in 1893, on syphilis and prostitution in relation to public health. ${ }^{7}$

As a student Blaschko was a close friend of the socialist doctor, Ignaz Zadek (18581931), who was decisive in developing Blaschko's interests in radical social reform. During the 1880s Blaschko was interested in occupational skin diseases. Although never a member of the SPD (the German Socialist Party), Blaschko was sympathetic to socialist ideas. He can be characterised as supportive of the revisionist views of the Sozialistiche Monathefte of Joseph Bloch (b. 1871). ${ }^{8}$ During the Charite strike in August 1893, Blaschko worked closely with Albert Kohn (1857-1926) and Zadek. Their aims included the abolition of prison-like discipline imposed on STD patients at the Charité, which was the central state hospital in Berlin. The ministerial official, Friedrich Althoff (18391908), conveyed his private sympathies to Blaschko, recognising the boycott as a means of pressurising the state to fund hospital refurbishment. ${ }^{9}$ Blaschko's radical sympathies can also be illustrated by his contact with Eduard Bernstein (1850-1932), during his London period of exile. Blaschko's radicalism posed a barrier to his obtaining hospital appointments at the Charite and the municipal Virchow hospital. ${ }^{10}$

Until the 1890 s sexually transmitted diseases were regarded in terms of moralistic disapproval. ${ }^{11}$ The drama, Ghosts by Henrik Ibsen (1828-1906) raised the spectre of what was very much a taboo subject. Concern arose over congenital blindness from syphilis, which particularly affected children, and over the policing of prostitution. The movement for the abolition of police controls on prostitution had an increasing impact in Germany. Blaschko was sympathetic. He established contacts with leading feminists, including Henriette Fürth (1861-1938) (a revisionist Social Democrat). ${ }^{12}$ The abolitionist movement challenged police controls on prostitutes at a time when the government and conservatives wished to impose draconian measures. It was argued that the dated morals police (Sittenpolizei) should be replaced by education of the male clientele of prostitutes. ${ }^{13}$ Blaschko was a member of the Bund für Mutterschutz (League for the Protection of Mothers), and was on its committee during 1905 , at a time when a number of doctors
Wellcome Unit for the 45-47 Banbury Road Oxford OX2 6PE, UK Paul Weindling 
like the sexologists, Iwan Bloch (1872$1922)^{14}$ and Max Marcuse (1877-1963) were influential in the League. In this context Blaschko should be seen as challenging traditions of repressive state policing. He resigned from the League along with other medical members when a debate erupted in 1908 over whether the League should take a lead in the campaign against the anti-abortion law. ${ }^{15}$

Blaschko's informal links with German socialists were helpful in organising facilities for free treatment of STDs and for education on their risks through workers' organisations. Albert Kohn of the Berlin sickness insurance fund (Berliner Ortskrankenkasse) was a useful contact. The sickness insurance benefits excluded obligatory Krankengeld for STDs, and this remained the situation until 1903. Blaschko wrote popular pamphlets for distribution by the sickness insurance funds and by the workers' health association, the ArbeiterSamariter-Bund. ${ }^{16}$ The links with sickness insurance funds were also helpful in providing statistics on the incidence of STDs. In 1900 a statistical survey was undertaken of all patients who were under treatment for STDs on 30 April of that year in Prussia with details of 41,000 cases returned by $65 \%$ of doctors. Blaschko established that there were high rates for STDs among students $(25 \%)$ and among those engaged in commerce, whereas rates were low among country labourers (9\%) and soldiers $(4 \%) .{ }^{17}$

Blaschko's links with dermatologists like Albert Neisser (1855-1916) and Edmund Lesser (1852-1918) provided a starting-point for the DGBG. ${ }^{18}$ This arose from three years' careful planning by dermatologists, who consulted state officials. French colleagues in 1901 established the Société française de prophylaxie sanitaire et morale. ${ }^{19}$ Although the DGBG was the result of the social concerns of reforming doctors, it found favour among Reich and Prussian government officials. ${ }^{20}$ Its inauguration on 19 October 1902 in the Berlin town hall was welcomed by Chancellor Bernhard von Bülow (1849-1929), and it received annual grants from the Prussian Medical Department. Althoff was elected an honorary member in $1902 .{ }^{21}$ Blaschko kept Althoff informed of developments, as when he sent copies of the protocol of the Brussels conference. ${ }^{22}$ The DGBG attracted a substantial lay membership, including the feminists Marie Stritt (1855-1928), Anna Pappritz (b. 1861) and Wally Zepler (b. 1865). In its first year the Society acquired nearly one thousand members, formed local groups and began to distribute pamphlets and to organise lectures. The DGBG developed public understanding of STDs, and helped to improve medical treatment, for which contact with sickness insurance funds and municipalities was important. For example, in 1903 the DGBG campaigned for increasing the number of hospital beds for STD patients in Berlin. ${ }^{23}$ Blaschko also supported close contacts with the Gesellschaft zur Bekämpfung des Kurpfuschertums, as a means of suppressing ineffective "quack" remedies.

As acknowledgement for his public services, Blaschko was awarded the title, Sanitätsrath, on 5 April 1904 by the Prussian state, which secured a police report to confirm that Blaschko was not a revolutionary agitator. ${ }^{24}$ In 1908 he received the title of Professor. ${ }^{25}$ Towards the end of 1918 Blaschko was promoted to the rank of Geheimer Sanitätsrat, a decision made just before the collapse of the Imperial administration.

In 1908 the Imperial Health Office called on Blaschko, Neisser and Lesser to advise on the problems of sexually transmitted diseases. Among the suggestions was the introduction of outpatient dispensary clinics on the pattern of those developed for tuberculosis and for infant welfare. ${ }^{26}$ In January 1910 a meeting was held under the auspices of the Prussian Medical Department when the possibilities of a national survey were discussed. Blaschko urged that there be uniform statistical procedures so that discrepancies between the Länder be ruled out. ${ }^{27}$ On 30 April 1910 Blaschko was invited to a meeting when the national survey of the incidence of STDs was agreed on. It was also decided to evaluate the efficacy of Ehrlich's salvarsan remedy for syphilis. $^{28}$

In November 1913 Blaschko helped to organise the survey on the incidence of STDs, which provided an indicator of prevalence in Berlin. During the First World War Blaschko was a progressive influence in policy-making matters. On 29 March 1915 the Reich Ministry of the Interior held a meeting on STDs in the army and on preventing their spread by returning troops. The conditions on the Eastern and Western fronts were compared. The "lax" morals of Polish families and French brothels were particular objects of concern. Proposals that there be compulsory notification of STDs, compulsory treatment of all soldiers with STDs and the informing of any infected soldier's wife were rejected. Blaschko was not among the invited experts, who included Edmund Lesser, an advocate of controls on prostitutes as the key to the problem. ${ }^{29}$ The military authorities under General von Bissing appreciated the relevance of Blaschko's advanced thinking to the problem of containment of STDs. In October 1915 Blaschko advised on the prevention and treatment of STDs in the occupied areas of Belgium. ${ }^{30}$ Bissing established a dispensary, but the distribution of condoms incurred the opposition of the Empress. ${ }^{31}$

Prior to the war, Blaschko keenly followed the debate on contraception and the so-called "birth strike". 32 By this time Blaschko and the DGBG were advocating the use of condoms as a prophylactic against infections-much to the annoyance of conservative social moralists and pro-natalists. Both the DGBG and conservative moralists lobbied the state on this issue. ${ }^{33}$ In 1911 Blaschko was criticised for his views on contraception by Max von Gruber (1853-1927), the Munich professor of hygiene and racial hygienist. Blaschko was a 
member of the more progressive Berlin branch of the Racial Hygiene Society by $1911 .{ }^{34}$ In 1917 he was on the committee of the Society. ${ }^{35}$ But he opposed their wartime proposals for compulsory health certificates prior to marriage on the ground that it was difficult to certify that a person was not infected by an STD, as the infection might be latent and without visible signs. ${ }^{36}$

STDs were central to the wartime debate on population policy when in March 1915 the Chancellor Theobald von Bethmann-Hollweg (1856-1921) demanded control of STDs in the interests of military efficiency and to protect the health and numbers of future generations. ${ }^{37}$ Bethmann-Hollweg's policies for social reform on the home front provided the experts of the DGBG with an opportunity to influence official policies, while outraging those on the völkisch right like von Gruber. ${ }^{38}$ When Blaschko's views on effective prevention were banned by the press office of the Bavarian War Ministry (even though allowed by the Prussian authorities), the ultranationalist, Julius Lehmann (1864-1935) distributed Blaschko's text as a handbill because of its importance for "Volk und Vaterland". ${ }^{39}$ On 30 November 1915 Neisser called for a far-reaching reform of legislation relating to STDs. ${ }^{40}$ The Prussian Ministry of the Interior convened an inter-ministerial committee for population policy, to which outside experts were invited. The meeting on STDs was part of a series of meetings on such topics as economic and agricultural implications of declining fertility, housing, measures to support "child rich" (that is, large) families, health education and midwifery reform. On 6 December 1915 STDs were on the agenda, and Blaschko, Lesser and Neisser were invited as outside experts. They were selected by the President Franz Bumm of the Reich Health Office as appreciating the importance of social hygiene. ${ }^{41}$ Discussion ranged over the loss resulting to the birth rate from STDs, the need for police controls over prostitutes, a wide-ranging programme of sex education, and restricting the right to treat STDs to the medical profession while increasing the number of beds and reducing the price of salvarsan. ${ }^{42}$ Officials accepted that it was inadvisable on hygienic grounds to ban condoms. The university professors, Lesser and Neisser advocated regulation leaving Blaschko in the minority as an abolitionist: the support of many noted dermatologists for regulation coincided with the coercive and highly moralistic views of the Imperial German ruling elite. The laws relating to prostitution were considered by the Prussian Committee for Medical Affairs on 14 March 1916.43 The expert advisers summoned for this meeting were once again Blaschko, Lesser and Neisser. Others present at this and at the prior meeting in December 1915 were the Prussian medical officials, Martin Kirchner (1854-1925) and Otto Krohne (1868-1928). A further sitting was held at the Reich Ministry of the Interior when arrangements for demobilisation were dis- cussed. ${ }^{44}$

In November 1916 the SPD was defeated by thirteen to eight votes in the Reichstag's committee for population policy on the issue of compulsory notification for STDs and compulsory medical treatment. It was agreed that the Chancellor should encourage sickness insurance funds to provide more extensive therapeutic facilities by extending the network of clinics. ${ }^{45}$ Blaschko supported the extension of the role of sickness insurances during the war, and he advised the sickness insurance funds in 1917.46 The Landesversicherungsanstalten were to finance clinics (Beratungsstellen) for diagnosis; therapy was to be provided by medical practitioners, and the costs for the uninsured were to be paid by the Landesversicherungsanstalt. STD clinics were first established in Hamburg in January 1914, and by July 1921 there were 164 clinics with over 100,000 patients. ${ }^{47}$

Blaschko continued to keep a watchful eye on pro-natalist attempts to ban contraceptives and various devices used to induce abortions. When the Prussian Medical Department drafted a law for the prevention of means for contraception and abortion, Blaschko wrote on behalf of the DGBG explaining that certain intrauterine syringes were necessary in the treatment of STDs. ${ }^{48}$ Although legislation on the problem of STDs was being drawn up by the authorities as part of a pro-natalist package of legislation on contraception, sterilisation and abortion, Blaschko must be seen as dissenting from these broader aims linking medical authority to imperialism and pronatalism..$^{49}$

On 16 January 1918 Blaschko attended a meeting at the Reich Health Office when the STD statistics were discussed. As a result of the recommendation of the inter-ministerial committee for population policy, and of the Reichstag committee for population policy, a new survey of the incidence of STDs was deemed to be necessary. It was suggested that this should cover a whole year because of monthly variations, but for reasons of practicality a one month period was ultimately agreed on. Blaschko reported on a further survey undertaken by the Verband der statistische Amter (the Association of Statistical Departments) in twenty cities over four weeks in 1914 . He considered that statistical returns from doctors were uneven and that a law should make it compulsory for doctors to supply such statistics. The meeting agreed with Blaschko that doctors should be paid for their reports. He advised on the categories of questions, and also recommended various means by which the counting of the same patient twice over could be avoided..$^{50}$

By January 1918 the military high command was pressing for pronatalist legislation on the basis of social hygiene: including measures to curb STDs. ${ }^{51}$ On 20 February 1918 the Reichstag committee for population questions considered a Bill concerning STDs. Although the government package of pronatalist legislation on abortion, STDs and contraception was to be debated by the 
Reichstag in November 1918, Germany's military and political collapse prevented its passing into law. Yet the need for legislation on STDs was perceived as greater than ever. Towards the end of 1918 three Berlin dermatologists petitioned the socialist Prussian Ministerpräsident, Paul Hirsch (1868-1938), for emergency measures to provide free treatment and advisory clinics for demobilised troops. On 2 and 4 December 1918 a meeting was held in the Prussian Ministry of the Interior on the problem of STDs in the context of demobilisation. Blaschko attended on 4 December along with other experts in social hygiene, including Benno Chajes (18801938), Alfred Grotjahn (1869-1931), Johannes Rabnow (1855-1933), and Ernst Kromayer (1862-1933). The presence of these medical experts on social hygiene was indicative of an important new grouping of medically oriented social hygienists during the Weimar period. It was agreed that free treatment for demobilised soldiers and their family dependants should be financed by the state and provided by municipalities. An estimated 30,000-40,000 soldiers (out of an army of 3.3 million) were infected. ${ }^{52}$ On 11 December 1918 Hirsch decreed legislation on sexually transmitted diseases. ${ }^{53}$ The military authorities were to pass on the names of soldiers with STDs to local authorities, who were to arrange for treatment. There could be compulsory treatment, and the infecting of a partner by someone knowing that they were infectious could incur three years' imprisonment. A special system of specialists was to be set up for the purposes of demobilisation, and these arrangements were to remain in force until 31 March 1919. The decree initiated in the various states discussion of compulsory treatment, notification and the possibilities of blackmail of those notified as infected..$^{54}$

On 15 April 1919 the Reich Ministry of the Interior considered the re-introduction of a law against STDs, and favoured compulsory notification of cases, prosecution of anyone infecting others with an STD, and the banning of "quacks" from treating STDs. ${ }^{55}$ Blaschko pointed out that more important than the availability of condoms was post-coital disinfection. ${ }^{56} \mathrm{~A}$ national survey of the incidence of STDs was carried out between 15 November and 14 December 1919 , and the results increased the pressure for legislation. ${ }^{57}$ On 20 February 1920 the Prussian Council for Population Policy asked the Prussian government to request national legislation from the Reich government, and this was supported by the Prussian Assembly on 25 February. ${ }^{58}$ A revised draft law was considered by the Reich Health Council on 30 March 1920.59 The issues of compulsory notification and a health certificate for prostitutes aroused heated controversy in the Prussian Assembly during February 1920.60 The legislation was reintroduced in the Reichstag in 1922, but was withdrawn because of socialist amendments. Owing to concern over a compulsory element in the law it incurred the opposition of lay healers and natural therapists. The law was criticised as inconsistent with the principle of a free choice of medical practitioner, and because of this failed to pass the Reichstag. ${ }^{61}$ In 1925 it was proposed to extend the compulsory element to all sexual disorders, and the bill again foundered. The law was eventually passed in March 1927 , and has remained the basis for current legislation. ${ }^{62}$

Blaschko's progressive views on education and contraception meant that he was a figure of considerable influence when social hygiene attained great prestige during the early years of the Weimar Republic. ${ }^{63} \mathrm{He}$ was a member of the Prussian and then the Reich Committee on Health Education. ${ }^{64}$ In 1920 Blaschko advised the Reich Health Council as a representative of the Berlin Racial Hygiene Society on the question of compulsory medical certificates prior to marriage. ${ }^{65}$ On 11 June 1920 the Reichstag approved a law for the distribution of a health education booklet to all marrying. Blaschko was among the experts in social hygiene that were consulted about its text. ${ }^{66}$

Blaschko was considered by the conservative medical faculty of the university for a new chair of social hygiene which the state had recommended in December 1918. Blaschko had been proposed as a medical expert on population policy. The conservative medical faculty replied that Blaschko lacked scientific distinction and moral standards. They were outraged at the suggestion that there would be less prostitution if the middle class, like the proletariat, engaged in pre-marital sexual intercourse. The faculty distorted Blaschko's view that earlier middle class marriage would reduce prostitution. ${ }^{67}$

Blaschko's influence was not limited to Germany. He advised Abraham Flexner (1866-1959) on his report on Prostitution in Europe for the Rockefeller-financed Bureau of Social Hygiene. ${ }^{68}$ Blaschko had the book translated into German under the auspices of the DGBG. The translator was Margarete Wolff, a niece. ${ }^{69}$ Flexner visited Blaschko shortly before the latter's death in March 1922, when investigating the need for American subsidies to German medical science. ${ }^{70}$

Blaschko has the distinction of having influenced the policies of both the German and British governments during the First World War. For on 5 June 1914 he gave evidence to the Royal Commission on Venereal Diseases (evidence was also given by Felix Plaut, a Munich psychiatrist). Blaschko answered questions relating to the various statistical surveys, based on mortality data and the statistics compiled by sickness insurance funds, the military, hospitals and associations of physicians. He expressed views on the incidence of STDs among certain occupational groups, and more generally as to its greater incidence among the German middle class. When the report was published in 1916, Blaschko obtained a copy via the neutral Netherlands. ${ }^{71}$ 
The military emergency of 1918 resulted in an emergency decree of December 1918. This gave physicians the exclusive right to treat disorders of the reproductive organs. Yet the political divisions and conflicts within parties over natural therapy and whether it was permissible to sanction a medical monopoly for the treatment of STDs delayed the passing of further legislation. Further draft legislation abolished the Sittenpolizei. Opinions remained polarised with opposition across the political spectrum to salvarsan therapy.

Blaschko's death on 26 March 1922 occurred when he was at the height of his influence. His successor in the DGBG, Georg Loewenstein (b. 1890), who from 1919 had acted as Blaschko's private secretary and editorial assistant with the DGBG's publications, carried on Blaschko's policies. ${ }^{72}$ Although the legislation for STDs was not passed until 1927, Blaschko can be seen to have been a central figure in modernising policies and social attitudes to a range of sexual and medical issues in Imperial and Weimar Germany.

Loewenstein represented a more rigorous blend of social theory, social medicine and socialism. Supporting the movement for municipal polyclinics, Löwenstein saw STDs as part of a comprehensive system of social welfare services. Yet the rub to this comprehensive system was that it involved compulsory detention of those found to be spreading STDs and compulsory treatment for syphilis with salvarsan. At the same time there was greater sexual explicitness which meant that STDs and associated issues like the provision of vending machines for contraceptives remained politically highly controversial.

The advent of Nazism saw the dismissal, persecution and either emigration or murder of many leading dermatologists and public health experts interested in STDs. As a fringe medical specialism dermatology had a relatively high proportion of Jewish physicians. Loewenstein emigrated to the United States where he was not able to utilise his expertise in dealing with STDs. Moreover, the German contribution to the developing of serological tests for syphilis as part of the League of Nations programme for biological standardisation was halted.

There is relatively little known about STDs in Nazi Germany, perhaps because the issue was overshadowed by racial priorities as well as the problem being an embarrassment to Nazi Germany once it was racially cleansed. The Nazi medical establishment was preoccupied with implementing compulsory sterilisation and the problems of mental health, as well as positive measures to promote the health and fertility of the racial elite. With the attention of public health experts fixed on the extremes of positive and negative eugenics, sexually transmitted diseases received less attention than hitherto. Despite official pronatalism and objections to the widespread availability of contraceptives, condoms continued to be valued for providing a barrier to infection. Certainly the DGBG suffered a loss in status. German experts in dermatology and prevention and treatment of STDs could no longer claim to be pioneering. Among all the horrific human experiments in concentration camps (which included the testing of new sera and drug therapies), the search for remedies to sexually transmitted diseases was not especially evident. Ironically, Hitler's nightmare of floods of STDs polluting the nation was to find a solution not under Nazism, but only after the defeat of Germany when penicillin curbed the spread of syphilis on an epidemic scale.

1 This paper is an extended and revised version of the introduction to: Weindling PJ with Slevogt U, Alfred Blaschko duction to: Weindling PJ with Slevogt U, Alfred Blaschko Diseases in Imperial and Weimar Germany: a Bibliography (Oxford: Wellcome Unit for the History of Medicine, 1992)

2 Blaschko's set of the Mitteilungen der Deutschen Gesellschaf zur Bekämpfung der Geschlechtskrankheiten are in the Radcliffe Science Library, Oxford.

3 Tennstedt F, 'Alfred Blaschko-das wissenschaftliche und sozialpolitische Wirken eines menschenfreundlichen Sozialhygienikers im Deutschen Reich', Zeitschrift für Sozialreform, 1979;25:513-23, 600-14, 646-67.

4 In 1917 sickness insurance fund earnings amounted to 7917.06 marks. See Geheimes Staatsarchiv Preussicher Kulturbesitz (hereafter GSTA) Dahlem, Bl. 415.

5 Blaschko is not, however, mentioned in: Nürnberger FG '100 Jahre Berliner Dermatologische Gesellschaft', '100 Jahre Berliner Dermatologisch

6 Jackson R. 'The Lines of Blaschko: a Review and Reconsideration. Observations on the Cause of Certain Unusual Linear Conditions of the Skin', $\mathrm{Br} \mathcal{F}$ Dermato 1976;95:349-60. Happle R, Lyonization and the Lines of Blaschko, Hum Genet 1985;70:200-6.

7 Blaschko A. Syphilis und Prostitution vom Standpunkte der öffentlichen Gesundheitspflege (Berlin, 1893).

8 For revisionism and social biology see Weindling PJ, Health, Race and German Politics between National Unification and Nazism (Cambridge, 1989), 119.

9 Tennstedt F, Alfred Blaschko, op cit. 604

10 Brömmer U, Die Bedeutung Alfred Blaschkos bei der Geschlechtskrankheiten in Deutschland, med. Diss. Geschlechtskrankheiten in Deutschland,
Humboldt-Universität zu Berlin, 1986: 23.

11 Linse U, 'Über den Prozess der Syphilisation-Körper und Sexualität um 1900 aus ärztlicher Sicht', Schuller A and Heim N, eds. Vermessene Sexualität. Berlin and Heidelberg, 1987:163-85.

12 For correspondence of Blaschko $A$ and Fürth $H$ between 3.1.1905 and 10.2.1906 (seven letters) see Fürth $H$ papers, International Institute of Social History, Amsterdam.

13 On abolitionism see Evans RJ, The Feminist Movement in Germany 1894-1933 (London and Beverly Hills, 1976) 41-5, 53-63, 120. Evans, 'Prostitution, the State and Society in Imperial Germany', Past and Present 1976;70:106-29.

14 On Bloch see Egger B, Iwan Bloch und die Konstitutierung der Sexualwissenschafi als eigene Disziplin (Düsseldorf, 1988).

15 The protocols of the League are in the Nachlas Schreiber, Bundesarchiv Koblenz. See also Nowacki B Der Bund für Mutterschutz (1905-1933) (Husum, 1983). Evans RJ, Feminist Movement, 122-39. Weindling PJ, Health, Race and German Politics, 252-7.

16 Labisch A, 'The Workingmen's Samaritan Federation Arbeiter-Samariter-Bund 1888-1933', fournal of Contemporary History, 1978;13:297-322. Tennstedt F, Vom Proleten zum Industriearbeiter. Arbeiterbewegung und Sozialpolitik in Deutschland 1800 bis 1914 (Cologne Sozialpolitik in Deutschland 1800 bis 1914 (Cologne,
$1983), 555-9$ for bourgeois social hygiene and socialism.

17 Hodann M. A History of Modern Morals (London, 1937), $119-20$

18 Schmitz S. Albert Neisser. Leben und Werk auf Grund neuer unveröffentlichter Quellen (Düsseldorf, 1968), pp. 54-56. Neisser informed Blaschko of earlier plans for "Syphilisgesellschaft".

19 Quétel C. History of Syphilis (Polity Press, Cambridge, 1990), 135.

20 GSTA Merseburg Rep 77 Tit 662 Nr 44 Beiakten 4 betr. die deutsche Gesellschaft zur Bekämpfung de Geschlechtskrankheiten

21 Geheimes Staatsarchir Preissischer Kulturbesit Merseburg Rep 92 Althoff AI Nr 234, letter of Neisser to Althoff.

22 GSTA Merseburg Rep 92 Althoff AI Nr 234, letters of Blaschko to Althoff 11 November 1902 and 31 January 1903. 
23 Stadtarchiv Berlin, Rep 00/1937 Akten der Stadtverordneten Versammlung, letter from DGBG of 28 October 1903 and debate in municipal assembly of 5 November 1903

24 GSTA Merseburg Rep 76 VIII A Nr 4151 Acten der Arzneiwissenschaft. Dr med Alfred Blaschko aus Freienwald approb. 9·iii·1881 als Arzt, Bl. 28-31.

25 ibid., Bl. 35 .

26 BAP $15.01 \mathrm{Nr} 11866$ Massnahmen gegen Geschlechtskrankheiten, 1907-9 Bl 8, 232-269 Denkschrift lechtskrankheiten, 1907-9 Bl 8, 232-269 Denkschrift zur Bekämpfung

27 GSTA Merseburg Rep 76 VIII B Nr 3798 Geschlechtskrankheiten 1910-1916 Bl. 67, meeting of 15 January 1910.

28 GHSTA M Rep 76 VIII B Nr 3798, Bl 58, Neisser from Breslau 21 October 1910. For the leading opponent of salvarsan, Dr Dreuw see Rep 76 VIII B Nr 3886 Handakte des Berliner Arztes Dr med Dreuw über Salvarsanbehandlung 1914. For Dreuw and the Imperial Health Office see BAP $15.01 \mathrm{Nr} 11867 \mathrm{Bl}$. 52, $191,266$.

29 GSTA Merseburg Rep 76 VIII B Nr 3798 Die Geschlechtskrankheiten, 1910-1916, Bl 78-86 Meeting of 29 March 1915. Bl 125-35 Memorandum of 28 January 1916 by Lesser. See also BA Potsdam 15.01 28 January 1916 by Lesser. See also BA Potsdam 15.01 $\mathrm{Nr} 11868$ Massnahmen gege

30 Bundesarchiv Potsdam Nr 11869 Bl. 96v, 390-3. For the minutes of the meeting see $\mathrm{Bl}$. 195-234 'Massnahmen ur Bekämpfung der Geschlechtskrankheiten 8 Oktober 1915. Einladung des General-Gouvernements in Belgien zur Brüssel, Brüssel Dezember 1915.

31 Hodann M. Modern Morals, pp. 80-81.

32 For overviews see Linse U, 'Arbeiterschaft und Geburtenentwicklung im Deutschen Kaiserreich von 1871', Archiv für Sozialgeschichte, vol. 12 (1972) 205-271. Woycke J, Birth Control in Germany 1871-1933 (London and New York, 1988). Usborne C, Fertility Control and and New York, 1988). Usborne C, Fertility Control and Population Policy in Germany 1910-1928, Open rationalisierten Triebe. Rassenhygiene, Eugenik und rationalisierten Triebe. Rassenhygiene, Eugenik und Geburtenkontrolle im Deutschen Kaiserreich, revised ver-
sion of Freie Universität Berlin PhD dissertation, 1988. sion of Freie Universität Berlin PhD dissertatio
GHSTA Merseburg Rep 76 VIII B Nr 2017.

33 GHSTA Merseburg Rep 76 VIII B Nr 2017 . of 3 March 1910, but does appear in the later list for that year: Internationale Gesellschaft für Rassen-Hygiene. Mitgliederliste vom 31 Dezember 1910 , p. 3. Deutsche Gesellschaft für Rassen-Hygiene. Mitgliederliste vom 31 Dezember 1913, Blaschko is described as "Professor für Haut- u. Geschlechtskranke an der Universität". Alfred Grotjahn was also a member of the Society by 1913.

35 He was a member of the Society's "Ausschuss", elected in 1917. See Mitteilungen der Berliner Gesellschaft für Rassenhygiene, no. 5 (1917), p. 4, and the list in the Rassenhygiene, no. 5 (1917), p. 4, and the list in the
pamphlet by Baur E, "Bevölkerungspolitik und Rassenpamphlet

36 Rott papers, Library of the Freie Universität Berlin, Vorberatung über die Frage des Austausches von Gesundheitszeugnissen vor der Eheschliessung. Ueber den gesetzlichen Austausch von Ehezeugnissen vor der Eheschliessung und über rassenhygienischen Eheverbote (Munich, 1917). von Soden K, Die Sexual1988), pp. 21-24.

37 BA Potsdam 15.01 Nr 11868 Massregeln gegen Geschlechtskrankheiten statement of 19 Weindling PJ, 'The Medical Profession, Social Hygiene and the Birth Rate in Germany, 1914-18', Wall $R$ and Winter J, eds. The Upheaval of War. Family, Work and Welfare in Europe, 1914-1918 (Cambridge, 1988), pp.

38 Julius Lehmann papers, Munich. Letter of Gruber to Lehmann $31 \cdot 3 \cdot 1915$.

39 Julius Lehmann, papers, Box 3 Politik. MS (by Lehmann JF) "Massregeln zur Bekämpfung der venerischen Krankheiten bei den Truppen".

40 GSTA M Rep 76 VIII B Nr 3798 Bl. 87-90.

41 GSTA Dahlem, letter of Bumm to Staatsekretär des Inneren 18.10.1915. BA Koblenz R 86/2375 Bd 1 Geburts- und Sterblichkeitsverhältnisse im Deutschen Reiche. letter of 18.10 .1915

42 GSTA Merseburg Rep 76 VIII B Nr 2018 Verhandlungen der Staatsregierung über den Geburtenrückgang. Bekämpfung der Geschlechtskrankheiten. GSTA Dahlem Rep 84a $\mathrm{Nr} 865$ betr. die Fragen des Geburtenrückganges und die Bekämpfung desselben 1913-1917, Bl. 43-44. Denkschrift des Ministers des 1913-1917, Bl. 43-44. Denkschrift des Ministers des
Innern über die Ergebnisse der Ministerialkommission für die Geburtenrückgangsfrage (Berlin, 1917), pp. 23-5, 113-8,

43 GSTA Merseburg Rep 76 VIII B Nr 3798 Bl. 160-166.

44 GSTA Merseburg Rep 76 VIII B Nr 3798 Bl. 213-217.

Bundesarchiv Potsdam 15.01/9343 Massregeln gegen den
Geburtenrückgang Bd 2 1916-17, Bl 116, article in
Vorwärts (4 November 1916). For continued SPD pressure for compulsory notification see Max Quarck, 'Für die kommende Generation', Vorwärts (10 November 1916 ) in 15.01/9343 Bl 146-7.

46 BAK R 86/1064 Deutsche Verein für VersicherungsWissenschaft 24 November 1917. Blaschko on Bekämpfung der Geschlechtskrankheiten und Lebensversicherung. See also Kaufmann P, Krieg, veschlechtskrankheiten und Arbeiterversicherung (Berlin, 1916).

47 BAK R 86/2375 Bd 1. Haustein H, 'The Struggle against Venereal Diseases in Germany', Health and Empire, vol. 1 (1921-22) 62-64.

48 GSTA Merseburg Rep 76 VIII B Nr 2017 Verhandlungen der Staatsregierung über den Geburtenrückgang vom Oktober 1915, Bl. 58-59 Blaschko to Krohne 3.10.1916.

49 Blaschko A 'Die neuen bevölkerungspolitische Gesetze', Vossische Zeitung, no. $95(21.2 .1918)$ in GSTA Merseburg Rep 76 VIII B Nr 2013 Zeitungsausschnitten, Bl. 30. Rep 76 VIII B Nr 2017 Bl 63, 183-185 concerning the DGBG's concern over the new law, 5.4.1917. Bl. 236-7 concerning support from the Reichstag and Reich Health Office, 7.5.1918.

50 BAK R 86/1064 Statistik der Geschlechtskrankheiten 28 Juni-5 Februar 1920, Besprechung über die statis28 Juni-5 Februar 1920, Besprechung über

51 BA Potsdam 15.01/9345 Geburtenrückgang 15.10.191728.2.1918, B1. 135-9 Memorandum by Chief of the General Staff of 23.1.1918 and Denkschrift der obersten Heeresleitung über die deutsche Volks- und Wehrkraft.

52 GSTA Merseburg Rep 76 VIII B Nr 3799 Die Geschlechtskrankheiten January 1917-März 1919 Bl 162-166, 171-175.

53 BA Potsdam 15.01 Nr 11881 Bekämpfung der Geschlechtskrankheiten. Verordnung vom 11 Dezember 1918.

54 GSTA Merseburg Rep 76 VIII B Nr 3799 Bl. 197-198. BA Potsdam 15.01 Nr 11881 Bekämpfung der Geschlechtskrankheiten-Verordnung vom 11 Dezember 1918 GSTA Dahlem Rep 84a/870 Berichte über Bevölkerungspolitischen Massnahmen, Bl 1 the reports indicated no cases of blackmail.

55 GSTA Dahlem Rep 84a866181.

56 GSTA Rep 84a866184, discussion of 24.4.1919.

57 Aktenstücke zu den Verhandlungen des Reichstages 1920/23, no 5801 appendix 2 , pp. 6766-9.

58 Verfassungsgebende Preussische Landesversammlung, (25 February 1920) cols. 9933-9965.

59 For the legislative proposals see Haustein $H$, 'The Struggle against Venereal Diseases in Germany', Health and Empire, vol. 1 (1921-22) 62-64.

60 Verfassungsgebende Preussische Landesversammlung, 121. Sitzung (25 February 1920) cols. 9921-68.

61 Aktenstücke zu den Verhandlungen des Reichstages 1920/23 (1923) no. 3523 , no. 5801 (8.5.1923) pp. 6745-6756 no. $5807(8.5 .1923)$ p. 6775 , no. 5801 pp. $6761-6769$, no. 5807 (8.5.1923) p. 6775 , no. 5801 pp. $6761-6769$, no. 7139 , no. 5938-5940 (13.6.1923) p 7144 , no. 5942-5943 7145 , no. 5971 0 p. 7230-7232, no. $5942-5943$ p. 7145 , no. 5971 pp. 7230-7232, no.
5988 p. 7257 , no. 5991 (18.6.1923) p. 7258. For repercussions in Prussia see Preussischer Landtag (18 April 1923) cols. 16465-6.

62 GSTA Dahlem Rep 84a Justizministerium Nr 8681925 1927. For an analysis of the law (and related issues) see Göckenjan G,' "und nagt in unheimlich geschäftigtiger Verborgenheit an dem Marke der Gesellschaft"Syphilisangst und Politik mit Krankheit', paper delivered to 8 . Fachtagung Sozialwissenschaftliche Sexualforschung 20.-22.6.1986 Düsseldorf.

63 Linse U, 'Alfred Blaschko: Der Menschenfreund als Überwacher. Von der Rationalisierung der SyphilisProphylaxe zur sozialen Kontrolle', Zeitschrift für SexualProphylaxe zur sozialen Kontrolle'

forschung, vol. $2(1989) 301-316$.
64 BA Potsdam $15.01 \mathrm{Nr} 9370$ Der Reichsausschuss für hygienische Volksbelehrung Bl. 1-7.

65 BA Potsdam $15.01 \mathrm{Nr} 9379 \mathrm{Bl} .70-157$. Health, Race and German Politics, pp. 361-5 for ensuing controversies.

67 GSTA Merseburg Rep 76 Va Sekt 2 Tit IV Nr 46 Bd 21 Bl 268.

68 Fexner A, Prostitution in Europe (New York, 1914).

69 Alfred Blaschko's working copy is with the offprint collection. See note by Blaschko $H$, concerning the translation.

70 Personal communication of 15.4.1991 from Blaschko $\mathrm{H}$. For the circumstances of this visit see Weindling PJ,
'The Rockefeller Foundation and German Biomedical 'The Rockefeller Foundation and German Biomedical Science, 1920-1940', Rupke N, ed. Science, Politics and
the Public Good. Essays in Honour of Margaret Gowing the Public Good. Essays in Honour

71 This copy of the report is with Blaschko papers at the Wellcome Unit, Oxford.

72 Leibfried $S$ and Tennstedt F, eds. Kommunale Gesundheitsfürsorge zwischen Kaiserreich und Nationalsozialismus autobiographische, biographische und gesundheitspolitische Anmerkungen von Dr Georg Loewenstein (Bremen, 1980). 